\title{
Presence of organochlorine pesticides and characterization of biomarkers in wild mice living in crop fields
}

\author{
Moises Andrade Herrera' ${ }^{1}$, Griselda Escalona Segura ${ }^{1}$, Mauricio González Jáuregul², \\ Rafael Reyna Hurtado', Jorge A. Vargas Contreras ${ }^{3}$, Jaime Rendón von Osten ${ }^{4 *}$ \\ ${ }^{1}$ El Colegio de la Frontera Sur. Unidad Campeche. Avenida Rancho Polígono 2-A, Ciudad Industrial, CP. 24500, Lerma. San Francisco de \\ Campeche. Campeche, México. Email: moandrade@ecosur.edu.mx (MAH), gescalon@ecosur.mx (GES), rafaelcalakmul@gmail.com (RRH). \\ ${ }^{2}$ Instituto de Ecología. Carretera antigua a Coatepec 351, El Haya, CP.91070, Xalapa. Veracruz, México. Email:mauglezj@gmail.com (MGJ). \\ ${ }^{3}$ Facultad de Ciencias Químico Biológicas. Universidad Autónoma de Campeche. Avenida Agustín Melgar S/N entre calle 20 y Juan de la \\ Barrera, Buenavista, CP. 24039, San Francisco de Campeche. Campeche, México. Email: jalbino64@hotmail.com (JAVC). \\ ${ }^{4}$ Instituto EPOMEX. Universidad Autónoma de Campeche. Campus VI. Av. Héroe de Nacozari 480. CP. 24070, San Francisco de \\ Campeche. Campeche, México. Email: jarendon@uacam.mx (JRvO). \\ * Corresponding Author.
}

The use of pesticides in crops bordering conservation areas poses risks for wildlife incidentally exposed; its effects in the Yucatan Peninsula, Mexico, are still unknown. Wild mice that inhabit farming land play a key ecological role, and can also be used as bioindicators of wildlife exposure to pollutants. The objectives of this work were to determine the presence of organochlorine pesticides (OC) in liver and evaluate the seasonal response of enzymatic biomarkers (BM) such as acetylcholinesterase (AChE), glutathione-S-transferase (GST), and catalase (CAT). Wild mice (Mus musculus) were captured between June 2015 and April 2016 in a watermelon crop of a rural community in Quintana Roo, Mexico. Individual mice were sacrificed in situ, followed by tissue dissection (liver, brain and skeletal muscle). Pesticides were determined by gas chromatography; BM activity was estimated by spectrophotometry. We captured 35 individuals, with a capture success of $2.33 \%$. The prevailing OCs detected were drines in both climatic seasons. The rainy season influenced the activity of biomarkers to a greater extent, since AChE showed a lower activity ( $16 \%$ and $40 \%$ in brain and liver, respectively). GST was activated during the same season (77 \% higher), while CAT did not show significant differences between seasons. There was no significant correlation between OC concentrations and biomarker activity, except for drines and $\mathrm{AChE}$ in the brain. OC concentrations recorded in the present work are below (2- and 20-fold lower) those reported in other works on rodents under controlled conditions. BM activity suggests that rainfall seem to exacerbate the effects of pesticides on mice; however, it seemingly does not pose a risk for their survival. The use of wild mice as bioindicators is a valuable and practical tool to detect disturbances derived from the use of pesticides in agricultural areas. Further research is recommended using a broader BM battery to identify those pollutants with the most severe effect on the physiology of wild animals incidentally exposed to pesticides.

El uso de plaguicidas en cultivos aledaños a áreas de conservación, significa un riesgo para la fauna silvestre expuesta accidentalmente cuyos efectos son desconocidos, particularmente en la Península de Yucatán, México. Los ratones silvestres que habitan las regiones agrícolas, desempeñan un papel ecológico importante, además pueden servir como bioindicador de exposición a contaminantes. Los objetivos del presente trabajo fueron determinar la presencia de plaguicidas organoclorados $(O C)$ en hígado y evaluar la exposición a partir de la respuesta temporal de los biomarcadores enzimáticos (BM), tales como acetilcolinesterasa (AChE), glutatión-S-transferasa (GST) y catalasa (CAT). Ratones silvestres (Mus musculus) fueron capturados entre junio de 2015 y abril de 2016 en un cultivo de sandía de una comunidad agrícola, en Quintana Roo, México. Los individuos fueron sacrificados in situ y se le diseccionaron los tejidos (hígado, cerebro y músculo esquelético). La presencia de plaguicidas se determinó por cromatografía de gases. La actividad de los BM se determinó por espectofotometría. Se capturaron 35 individuos, con un éxito de captura de $2.33 \%$. Los OC más detectados fueron los drines en ambas temporadas climáticas. La temporada lluviosa influyó más en la actividad de los biomarcadores, ya que la AChE mostró menor actividad (16 y $40 \%$ en cerebro y músculo respectivamente), la GST aumentó su actividad para la misma temporada (77 \% mayor), y finalmente la CAT no mostró diferencias significativas entre temporadas. No hubo correlación significativa entre las concentraciones de OC y la actividad de BM, a excepción de los drines y la AChE en cerebro. Las concentraciones de OC encontradas en el presente trabajo, están por debajo (entre 2 y 20 veces) de las reportadas en otros trabajos con roedores en condiciones controladas. La actividad de los BM refleja que las lluvias parecen acentuar los efectos de los plaguicidas sobre los ratones, sin embargo, puede no representar un escenario de riesgo para su sobrevivencia. La utilización de ratones silvestres como bioindicadores, es una herramienta útil y práctica para vislumbrar disturbios ocasionados por el uso de plaguicidas en zonas agrícolas. Se recomiendan trabajos complementarios y ampliar la batería de BM, para poder determinar con mayor precisión cuales son los contaminantes que afectan en mayor medida la fisiología de los animales silvestres expuestos accidentalmente.

Keywords: Acetylcholineterase; catalase; glutathione-S-transferase; biomarkers; Mus musculus; organochlorine pesticides; wildlife

(c) 2018 Asociación Mexicana de Mastozoología, www.mastozoologiamexicana.org

\section{Introduction}

Technology-dependent agriculture (hereinafter called tech agriculture) involving the use of high amounts of pesticides poses a risk to wildlife that comes into contact with these toxic compounds, which may cause still unknown health effects. The continued application of pesticides and other agrochemicals to crop fields causes acidification, loss of soil biodiversity, and soil toxicity (Givaudan et al. 2014). Pesticides not only affect the target pest species, but also impact wildlife living in and around agricultural fields (Johnston, 
2000). The damage caused by pesticides on exposed organisms depend mainly on their toxicokinetics (uptake route and distribution) and toxicodynamics (effects on physiology and metabolism) and is influenced by external factors such as pesticide nature, chemical composition, persistence, dose, and time of exposure, as well as by the health status and susceptibility of the exposed organism (Ramírez and Lacasana 2001). The main characteristics of organochlorine pesticides include high persistence, mobility across great distances from their source of application, bioaccumulation, and long-term adverse effects (Mackay et al. 2001).

In this sense, the vertebrate group with the most severe adverse effects from incidental poisoning in the wild documented to date (Köhler and Triebskorn 2013), since they are deemed highly sensitive to pesticide exposure. In contrast, a group that has received little attention as to harm caused by pesticides is rodents, mainly because these are also considered as pests; however, this neglects the important ecological roles they play, mainly regarding seed dispersal and control of other pests such as insects and other invertebrates, besides being preyed by higher predators (Ceballos 2005).

In general, small mammals have been used as proxies to validate human exposure models by various environmental protection organizations. For example, the USEPA (United States Environmental Protection Agency) has commonly used rodents as indicators of human and environmental protection (Sheffield et al. 2001). Particularly, murine models have been used in the characterization of various effects of pesticides under controlled conditions. These comprise the evaluation of tolerance thresholds by determining the lethal dose $50\left(\mathrm{LD}_{50}\right)$ - the dose that kills $50 \%$ of the test population (Dell'Omo et al. 2003; Hirano et al. 2017) and adverse effects by endocrine disruption (Bhaskar and Mohanty 2014; Ghodrat et al. 2014), oxidative stress (Zhao et al. 2016; Morales-Prieto and Abril 2017; Latchoumycandane and Mathur 2002), genotoxic effects (Peris-Sampedro et al. 2016), or neurotoxic effects (Chen et al. 2016; Dell'Omo and Shore 1996; Westlake et al. 1983). All these studies have involved the application of various doses of one or more (mixtures) pesticides.

However, studies that consider mice as bioindicators of environmental conditions for wildlife are scarce. Population dynamics of rodents has been used as an indicator of disturbance in polluted areas. These studies have focused mainly on accidental deaths and population declines caused by acute exposure to organophosphate pesticides (OF) and carbamates (CB) (Barrett and Darnell 1967; Giles 1970; Sheffield et al. 2001). For example Block et al. (1999) assessed the long-term population impact of the pesticide OF Counter (terbufos), based on population parameters in two wild mice species (Peromyscus maniculatus and P. leucopus) in an agricultural field in lowa, USA, and concluded that OF has no apparent influence on reproduction and other population parameters that would affect their long-term demography. Other studies conducted in free-living mice evaluated the accumulation of persistent organic pollutants (POPs) in tissues (Perez-Gonzalez et al. 2017), or the effect of various pollutants at the histological level (Gomez-Ugalde 2003), or with a biochemical approach by analyzing enzymatic biomarkers (BM; Andrade-Herrera 2011; Chi Coyoc et al. 2016).

In Mexico, studies reporting the influence of crop pesticides on wild rodents are scarce. Specifically in the Yucatan peninsula, these studies focus on the presence and accumulation of pesticides (Rendon-von Osten et al. 2005; Charruau et al. 2013), and relatively few studies report harmful effects to the fauna surrounding farming areas where pesticides are used (Noreña-Barroso et al. 2004; Cobos et al. 2006; Buenfil-Rojas et al. 2016). Accordingly, in the state of Quintana Roo, particularly in the Maya area, the main tech crops are sugar cane, Maradol papaya and watermelon (SAGARPA 2015). These involve the use of various technological packages based on the use of agrochemicals to achieve high crop yields. For example, Endosulfan 35 Le Cag $^{\circledR}$ (endosulfan), Furadan $^{\circledast}$ (carbofuran), Herbipol ${ }^{\circledR}$ (2.4-D Amine) and Cerillo ${ }^{\circledR}$ (paraquat), Lannate ${ }^{\circledast}$ (methomyl) or Velfosato ${ }^{\circledast}$ (glyphosate) were recorded during field trips as the main pesticides used. It was noted that these pesticides are applied in excessive amounts, and farmers apply them disregarding the safety requirements (personal protection equipment).

Therefore, the lack of studies in the region analyzing the effects of tech agriculture on wildlife health, and in particular as regards small mammals, made it necessary to generate knowledge to provide evidence about the potential risks for these animals. Thus, the aim of the present study was to analyze the influence of the pesticides used in a tech watermelon crop on wild mice (Mus musculus). This was done by first determining the presence of pesticides in liver tissue of individuals captured, followed by characterizing the toxic effects through enzymatic biomarkers (AChE in brain and muscle; GST and CAT in liver), and finally by exploring the relationship between the pesticides detected and the activity of biomarkers.

\section{Materials and Methods}

Field Work. The sampling site is located at coordinates $19^{\circ}$ $35^{\prime} 24.70^{\prime \prime} \mathrm{N},-89^{\circ} 10^{\prime} 51.20^{\prime \prime} \mathrm{W}$, in the Municipality of José María Morelos, Quintana Roo, in a tech watermelon crop within the Mayan community named $X$ noh Cruz (Figure 1). The area is surrounded by rainfed maize fields and forest patches, and is adjacent to the Bala'Ka'ax Wildlife Protection Area (APFFBK).

Specimens were captured between June 2015 and April 2016 using 50 Sherman $^{\circledR}$ traps placed every five meters on both sides along a $125 \mathrm{~m}$ transect across the crop field. Traps were baited with a mixture of oats and vanilla and left overnight. The individuals captured were identified using field guides, and standard morphometric measurements were recorded. Then, these individuals were killed in situ by cervical dislocation according to NOM-033-SAG/ZOO- 2014, which stipulates the humane killing of domestic and wild animals; brain, liver and skeletal muscle samples were taken 


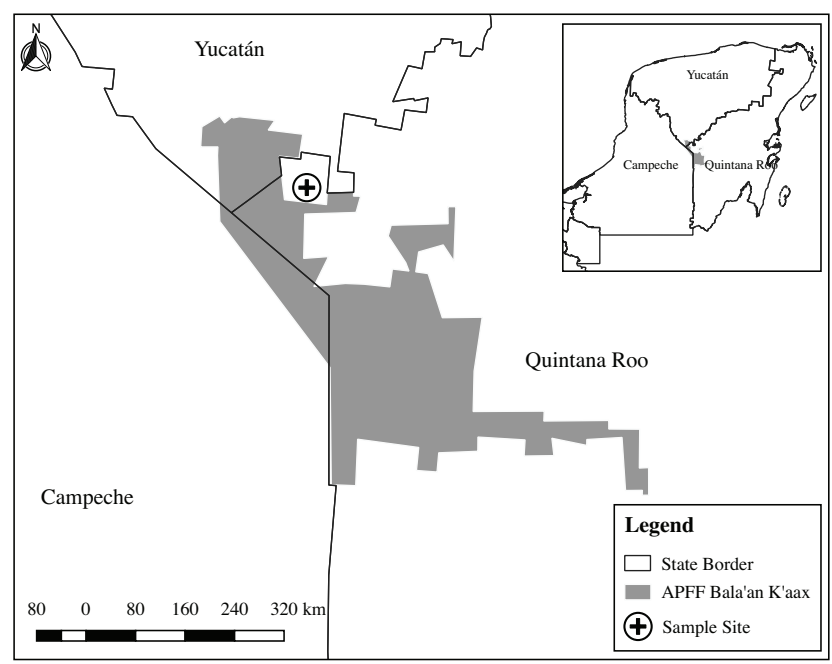

Figure 1. Sampling area, located in coordinates $19^{\circ} 35^{\prime} 24.70^{\prime \prime} \mathrm{N},-89^{\circ} 10^{\prime} 51.20^{\prime \prime} \mathrm{W}$, within the Mayan community of Xnoh Cruz, municipality of José María Morelos, Quintana Roo, which is adjacent to the Bala'an 'k'aax APFF.

for subsequent analysis. Tissues were stored in liquid nitrogen, transported to the laboratory, and stored at $-80^{\circ} \mathrm{C}$.

Laboratory work. Laboratory work was divided into two phases: the first determined the presence of organochlorine pesticides $(\mathrm{OC})$ in mouse liver tissue; the second characterized the effect of exposure to the various xenobiotics by assessing three biomarker enzymes: acetylcholinesterase (AChE) that reflects neurotoxicity, glutathione-S-transferase (GST) that indicates detoxification processes (phase II biotransformation), and catalase (CAT), an oxidative stress biomarker.

Determination of Pesticides in Liver Tissue. High-purity solvents were used ( $98 \% \mathrm{HPLC})$; glass material was washed with Extran ${ }^{\circledast}$ and rinsed with distilled water, then dried for 4 hours at $200^{\circ} \mathrm{C}$ and rinsed with acetone and hexane.

The analyses of pesticides in liver tissue of mice were performed according to the method described by Zhang et al. (2007). A fraction of liver tissue was collected, ovendried for $24 \mathrm{~h}$ at $45^{\circ} \mathrm{C}$, and weighed for subsequent analysis. Any chemicals in samples were extracted with a mixture of acetone:hexane (1:1) in a sonicator for $20 \mathrm{~min}$. After extraction, the amount of fat was determined to estimate the concentrations of pesticides on fat basis ( $\mu \mathrm{g} / \mathrm{g}$ of fat). Samples were purified through a glass column packed with $7 \mathrm{~g}$ of silica gel and $1 \mathrm{~g}$ of sodium sulfate. Afterwards, samples were eluted with $20 \mathrm{ml}$ of hexane, $20 \mathrm{ml}$ of a 1:1 mixture of dichloromethane and hexane, and $20 \mathrm{ml}$ of dichloromethane; then, samples were immediately evaporated to dryness and resuspended in $50 \mu \mathrm{l}$ of hexane for testing through gas chromatography. Pollutants were quantified using a Varian 3800 gas chromatograph with a $\mathrm{Ni}^{63}$ electron capture detector (GC-ECD) and equipped with a HT8 capillary column $(60 \mathrm{~m} \times 0.25 \mathrm{~mm} ; 25 \mu \mathrm{m}$ film thickness; SGE Analytical Science, USA). Injector and detector temperatures were $150{ }^{\circ} \mathrm{C}$ and $350{ }^{\circ} \mathrm{C}$, respectively. Pollutant concentrations were calculated through the area under the curve with the software Star Chromatography Workstation version 6 , and through the calibration of standards. Pesticides were identified and quantified using a mixture of 20 OC pesticide standards, CRM No. SUPELCO ${ }^{\circledR} 47426$ EPA CLP Organochlorine Pesticide Mix, and the Sigma-Aldrich standards Mirex No. 45887, 2.4'-DDE No. 36663, 2.4'-DDD No. 35485 and 2.4'-DDT No. 45839, which were pooled into families for testing (Table 1).

Activity of enzymatic biomarkers (BM). The three BM were analyzed in specific tissues according to their target organ, with AChE tested in brain and skeletal muscle, while GST and CAT were analyzed in liver. For the three BM, all samples were homogenized for $20 \mathrm{sec}$. in a homogenizer (PRO Sci-

Table 1. Organochlorine (OC) pesticides analyzed in liver tissue of Mus musculus; LD = limit of detection, LR = Limit of Report

\begin{tabular}{|c|c|c|c|}
\hline $\begin{array}{c}\text { Isomer and/or metabolites } \\
\text { analyzed }\end{array}$ & $\begin{array}{l}\text { LD } \\
\mu \mathrm{g} / \mathrm{g}\end{array}$ & Group & $\begin{array}{c}\mathrm{LR} \\
\mu \mathrm{g} / \mathrm{g}\end{array}$ \\
\hline$\alpha \mathrm{HCH}$ & 0.003 & \multirow{4}{*}{$\mathrm{HCHs}$} & \multirow{4}{*}{0.007} \\
\hline$\beta \mathrm{HCH}$ & 0.004 & & \\
\hline$\chi \mathrm{HCH}$ & 0.003 & & \\
\hline$\delta \mathrm{HCH}$ & 0.002 & & \\
\hline Aldrin & 0.004 & \multirow{5}{*}{ DRINES } & \multirow{5}{*}{0.0018} \\
\hline Dieldrin & 0.004 & & \\
\hline Endrin & 0.009 & & \\
\hline Endrin aldehyde & 0.010 & & \\
\hline Endrin ketone & 0.005 & & \\
\hline Endosulfan I (alpha) & 0.005 & \multirow{3}{*}{ Endosulfans } & \multirow{3}{*}{0.007} \\
\hline Endosulfan II (beta) & 0.006 & & \\
\hline Endosulfan sulfate & 0.005 & & \\
\hline $0, p^{\prime} D D E$ & 0.005 & \multirow{6}{*}{ Dldd } & \multirow{6}{*}{0.001} \\
\hline$p, p^{\prime} D D E$ & 0.004 & & \\
\hline$o, p^{\prime} D D D$ & 0.031 & & \\
\hline$p, p^{\prime} D D D$ & 0.025 & & \\
\hline o,p'DDT & 0.013 & & \\
\hline $\mathrm{p}, \mathrm{p}^{\prime} \mathrm{DDT}$ & 0.010 & & \\
\hline Trans Chlordane & 0.004 & \multirow{2}{*}{ Chlordanes } & \multirow{2}{*}{0.009} \\
\hline Cis Chlordane & 0.004 & & \\
\hline Methoxychlor & 0.018 & Methoxychlor & 0.01 \\
\hline Mirex & 0.006 & Mirex & 0.006 \\
\hline Heptachlor & 0.004 & \multirow{2}{*}{ Heptachlor } & \multirow{2}{*}{0.013} \\
\hline Heptachlor epoxide & 0.004 & & \\
\hline
\end{tabular}

entific $250^{\circledR}$ ), using the specific buffer for each BM according to the method used. AChE activity was determined as per the method of Ellman et al. (1961), adapted to microplate (Guilhermino et al. 1996); samples were prepared with a 0.1 $\mathrm{M}$ potassium phosphate buffer, $\mathrm{pH}$ 7.2. Enzyme kinetics was recorded at $414 \mathrm{~nm}$ and expressed in units (U) of hydrolyzed acetylcholine per minute per $\mathrm{mg}$ of protein using an extinction coefficient of $13.6 \times 10^{3} \mathrm{M}^{-1} \mathrm{~cm}^{-1}$. GST activity was determined according to the method described by Habig et al. (1974). A $0.1 \mathrm{M}$ solution of potassium phosphate buffer, pH 6.5, was used for sample preparation, and enzyme kinetics was read at $340 \mathrm{~nm}$, expressing activity as $U$ of S-(2.4-dinitrophenyl) glutathione per minute per milligram of protein, using an absorption coefficient of $9.6 \times 10^{3} \mathrm{M}^{-1}$ $\mathrm{cm}^{-1}$. CAT activity was measured through the decrease in $\mathrm{H}_{2} \mathrm{O}_{2}$ at $240 \mathrm{~nm}$ using the method by Aebi (1984) for example, methanol, ethanol, formic acid, phenols, with the con- 
sumption of $1 \mathrm{~mol}$ of peroxide (peroxide activity, using a 50 $\mathrm{mM}$ solution of potassium phosphate buffer of $\mathrm{pH} 7$, with activity expressed as $U$ of hydrogen peroxide produced per minute per milligram of protein. Protein concentration was determined by the method of Bradford (1976) at $595 \mathrm{~nm}$, expressed as $\mathrm{mg} / \mathrm{ml}$. In all cases, activity was determined using microplates $\left(\right.$ Corning $\left.^{\circledR}\right)$ in a spectrophotometer (Thermo Scientific Multiskan Spectrum ${ }^{\oplus}$ ).

Statistical analyses. All analyzes were performed using the software $\mathrm{R}$ version 3.2.4 (R Core Team, 2016). Compliance of BM activity with the assumption of a normal distribution was tested using a Shapiro-Wilk test, and differences were evaluated by comparing BM activity between climatic seasons (raint-dry), using a Student's $t$-test when the data were normally distributed, or with a Wilcoxon test otherwise (Table 2); the significance level used was $a \leq 0.05$ (Zar, 2010). Subsequently, the measures of central tendency and dispersion of pesticides were determined with the package NADA 1.6-1 (Lopaka 2013), taking into account left-censored data according to the chromatograph detection limit.

Table 2. Average activity of BMs per climatic season, with values expressed as U/ $\mathrm{min} / \mathrm{mg}$ protein. Also shown are the statistical $t$ values (parametric), W (non-parametric); $\mathrm{SD}=$ standard deviation; $\max =$ maximum value; $\min =$ minimum value; $\mathrm{DF}=$ degrees of freedom; $p=$ statistical probability; ${ }^{*} \leq 0.05,{ }^{* *} \leq 0.01,{ }^{* * *} \leq 0.001$.

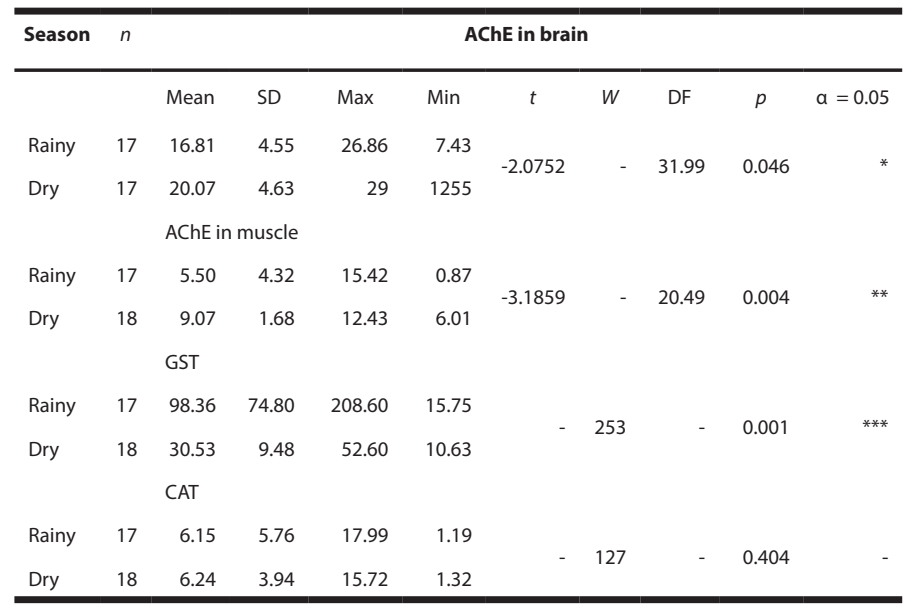

The "vegan" package (Oksanen et al. 2017) was used to perform correlations between the concentrations of pesticides detected (classified by chemical family) in liver and the BM analyzed. These correlations were explored using rank-transformed data (Spearman correlations), as concentration data were left-censored by the limits of detection and quantification (Helsel 2012).

\section{Results and Discussion}

This work reports the concentrations of pesticides in liver tissue (on fat, dry weight, and wet weight bases), as well as their potential effects characterized from the expression of three enzymatic BMs in three different wild-mice tissues. Adult individuals of Mus musculus were chosen as target species, because this was the dominant mouse species captured in sampling, as well as for its abundance in the study area, being a natural inhabitant in maize crop fields that surround watermelon crops (Alcérreca et al. 2009). The remaining animals were not deposited in any biological collection, given the poor condition of skin and skeleton (mainly the skull) after dissections. A total of 35 individuals were captured during field work (17 in the wet season and 18 in the dry season), over 30 nights of trapping, with a $2.33 \%$ capture success.

Presence of OC Pesticides in Liver Tissue. Of the 24 OC pesticides analyzed, those most frequently detected in the wet season belong to the "drines" family (aldrin, endrin, endrin aldehyde, endrin ketone, and dieldrin), which were detected in 10 individuals, followed by hexachlorocyclohexanes $(\mathrm{HCHs})$, detected in 7 specimens; in contrast, the least detected pesticide was methoxychlor, found in just two individuals. In the dry season, drines were also the pesticides most frequently detected in the 18 individuals analyzed, along with derivatives of dichloro-diphenyl-trichloroethane (DDT) and heptachlorine, with each detected in eight individuals; similar to the wet season, methoxychlor was the least detected pesticide, identified in only three specimens (Table 4).

On the other hand, the chemicals found in higher concentrations in both seasons were DDT isomers and methoxychlor, with peak concentrations of 702 and 524 $\mu \mathrm{g} / \mathrm{g}$ fat, respectively, both in individuals caught in the dry season. The chemical recorded in the lowest concentration was chlordane in both seasons, with a mean concentration of $6.63 \pm 11.3 \mu \mathrm{g} / \mathrm{g}$ fat and $15.02 \pm 29.3 \mu \mathrm{g} / \mathrm{g}$ fat in the wet and dry seasons, respectively.

The concentrations found in this study are below the exposure-related toxicity thresholds (mainly via ingestion) reported in various investigations on wild rodents under controlled laboratory conditions (Jefferies et al. 1973; Morris 1968; Sheffield et al. 2001; Wolfe and Esher 1980), which are 2- to 20-fold higher versus those reported here. These works were conducted primarily to set lethal doses and tolerances to various $\mathrm{OC}$ including drines, $\mathrm{HCHs}$ and DDTs; these works report both physiological and behavioral impairment, but only some report OC content in tissues.

A fact worth considering is that bioaccumulation in wild mammals is mainly driven by ingestion, although pollutants may also be absorbed through the skin or by inhalation (Linder and Joermann 2001). In this regard, the work on wild rodents in free-living conditions focus mainly on evaluating variations in population size or recording presence/absence in areas where OC pesticides have been used (Sheffield et al. 2001). The few studies that quantify the presence of $O C$ in tissues have been carried out primarily to identify DDT, dieldrin and heptachlor residues. In the case of DDT, the values found in mice in this study (between 0.001 and $1.834 \mu \mathrm{g} / \mathrm{g}$ dry weight) are similar to those reported by Lincer and Sherburne (1974) wet weight, ranging between 0.01 and $0.13 \mu \mathrm{g} / \mathrm{g}$ dry weight. In addition, Laubscher et al. (1971), in crop fields in Tucson, Arizona, found DDT and its metabolites at concentrations between 0.006 to 0.92 $\mu \mathrm{g} / \mathrm{g}$ wet weight in liver of Peromyscus eremicus and P. man- 


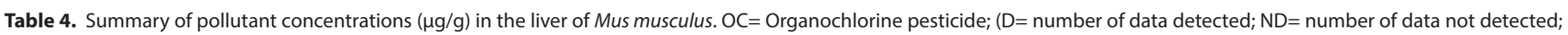
$\mathrm{SD}=$ standard deviation

Weight Fat

\begin{tabular}{|c|c|c|c|c|c|c|c|c|c|c|c|c|c|c|}
\hline \multirow[b]{2}{*}{ OC } & \multicolumn{7}{|c|}{ Rainy } & \multicolumn{7}{|c|}{ Dry } \\
\hline & $\mathrm{D}$ & ND & ND \% & Min & Max & Mean & SD & $\mathrm{D}$ & ND & ND \% & Min & Max & Mean & SD \\
\hline $\mathrm{HCHs}$ & 7 & 10 & 58.820 & 0.007 & 82.213 & 10.340 & 28.370 & 5 & 13 & 72.222 & 0.007 & 303.116 & 23.370 & 75.940 \\
\hline DRINES & 10 & 7 & 41.176 & 0.002 & 135.532 & 21.690 & 43.936 & 8 & 10 & 55.555 & 0.002 & 279.350 & 22.691 & 66.579 \\
\hline ENDOSULFAN & 4 & 13 & 76.470 & 0.007 & 89.165 & 23.127 & 27.844 & 5 & 13 & 72.222 & 0.007 & 195.783 & 18.027 & 48.257 \\
\hline DDTs & 4 & 13 & 76.470 & 0.010 & 303.812 & 39.522 & 111.434 & 8 & 10 & 55.555 & 0.010 & 702.315 & 45.947 & 170.208 \\
\hline CHLORDANES & 9 & 8 & 47.058 & 0.009 & 32.109 & 6.633 & 11.318 & 6 & 12 & 66.666 & 0.009 & 120.856 & 15.023 & 29.304 \\
\hline HEPTACHLOR & 5 & 21 & 70.588 & 0.013 & 54.537 & 10.606 & 17.970 & 8 & 10 & 55.555 & 0.013 & 227.825 & 18.473 & 54.433 \\
\hline METHOXYCHLOR & 2 & 15 & 88.235 & 0.010 & 232.528 & 232.530 & 0.010 & 3 & 15 & 83.333 & 0.010 & 524.625 & 60.177 & 137.962 \\
\hline
\end{tabular}

Wet Weight

\begin{tabular}{|c|c|c|c|c|c|c|c|c|c|c|c|c|c|c|}
\hline \multirow[b]{2}{*}{ OC } & \multicolumn{7}{|c|}{ Rainy } & \multicolumn{7}{|c|}{ Dry } \\
\hline & D & ND & ND \% & Min & Max & Mean & SD & D & ND & ND \% & Min & Max & Mean & SD \\
\hline $\mathrm{HCHs}$ & 7 & 10 & 58.820 & 0.005 & 0.023 & 0.009 & 0.007 & 5 & 13 & 72.222 & 0.004 & 49.930 & 2.770 & 12.780 \\
\hline DRINES & 7 & 10 & 58.820 & 0.002 & 0.042 & 0.009 & 0.013 & 8 & 10 & 55.555 & 0.002 & 0.079 & 0.012 & 0.024 \\
\hline ENDOSULFAN & 4 & 13 & 76.470 & 0.007 & 0.031 & 0.028 & 0.001 & 5 & 13 & 72.222 & 0.007 & 0.080 & 0.015 & 0.022 \\
\hline DDTs & 4 & 13 & 76.470 & 0.001 & 0.094 & 0.019 & 0.031 & 8 & 10 & 55.555 & 0.001 & 0.200 & 0.021 & 0.057 \\
\hline CHLORDANES & 9 & 8 & 47.058 & 0.004 & 0.357 & 0.028 & 0.087 & 6 & 12 & 66.666 & 0.003 & 0.064 & 0.010 & 0.016 \\
\hline HEPTACHLOR & 5 & 21 & 70.588 & 0.003 & 0.017 & 0.007 & 0.009 & 8 & 10 & 55.555 & 0.003 & 0.065 & 0.009 & 0.014 \\
\hline METHOXYCHLOR & 2 & 15 & 88.235 & 0.010 & 0.072 & 0.072 & 0.000 & 3 & 15 & 83.333 & 0.008 & 0.148 & 0.016 & 0.040 \\
\hline
\end{tabular}

Dry Weight

\begin{tabular}{|c|c|c|c|c|c|c|c|c|c|c|c|c|c|c|}
\hline \multirow[b]{2}{*}{ OC } & \multicolumn{7}{|c|}{ Rainy } & \multicolumn{7}{|c|}{ Dry } \\
\hline & D & ND & ND \% & Min & Max & Mean & SD & $\mathrm{D}$ & ND & ND \% & Min & Max & Mean & SD \\
\hline $\mathrm{HCHs}$ & 7 & 10 & 58.820 & 0.007 & 0.035 & 0.011 & 0.009 & 5 & 13 & 72.222 & 0.007 & 0.125 & 0.019 & 0.029 \\
\hline DRINES & 7 & 10 & 58.820 & 0.002 & 0.057 & 0.012 & 0.018 & 8 & 10 & 55.555 & 0.002 & 0.943 & 0.066 & 0.229 \\
\hline ENDOSULFAN & 4 & 13 & 76.470 & 0.007 & 0.037 & 0.037 & 0.001 & 5 & 13 & 72.222 & 0.007 & 1.040 & 0.070 & 0.263 \\
\hline DDT & 4 & 13 & 76.470 & 0.001 & 0.127 & 0.025 & 0.043 & 8 & 10 & 55.555 & 0.001 & 1.834 & 0.122 & 0.449 \\
\hline CHLORDANES & 9 & 8 & 47.058 & 0.006 & 0.765 & 0.054 & 0.189 & 6 & 12 & 66.666 & 0.009 & 0.821 & 0.060 & 0.202 \\
\hline HEPTACHLOR & 5 & 21 & 70.588 & 0.004 & 0.023 & 0.008 & 0.010 & 8 & 10 & 55.555 & 0.004 & 0.094 & 0.013 & 0.021 \\
\hline METHOXYCHLOR & 2 & 15 & 88.235 & 0.010 & 0.097 & 0.097 & 0.000 & 3 & 15 & 83.333 & 0.010 & 0.216 & 0.028 & 0.056 \\
\hline
\end{tabular}

iculatus; these levels are up to five-fold higher than those recorded in this study ( 0.0001 to $0.200 \mu \mathrm{g} / \mathrm{g}$ wet weight).

However, the concentrations found here are far lower than those reported by Chi Coyoc et al. (2016) for DDTs, $\mathrm{HCHs}$ and drines $(0.876,0.546$, and $0.451 \mu \mathrm{g} / \mathrm{g}$ dry weight basis respectively) in liver of wild rodents (Oryzomys couesi, Peromyscus leucopus and Reithrodontomys gracilis). These concentrations were up to 35 (DDT), 49 ( $\mathrm{HCHs}$ ) and 37 (Drines) times higher than those recorded in this study. These results suggest that the concentrations observed in this case may not pose a risk for the rodents exposed; however, the effects of the various pollutants are influenced by a number of factors - both environmental and physiological intrinsic to each species and even to each individual (Peakall and McBee 2001).

Finally, in general terms, there is a higher concentration of all OCs in the dry season than in the rainy season (Table 4). This could be due to the fact that rain leads to the partial leaching of toxic compounds to greater soil depths, thus reducing the exposure of organisms that live at the surface (González Valdez et al. 2013). An additional factor is the clayey silt soil in the sampling area (Andrade Herrera et al. 2018), which favors the leaching of pollutants given its low organic matter content, which adsobs OCs and makes them more persistent in upper soil layers (Cárdenas and Márquez 2015). Furthermore, factors associated with temporality may also account for the higher concentration of OCs in the dry season; for example, this coincides with the winter season, during which organisms move less due to the low temperatures (most reproductive periods occur in the rainy season), so that fat content of organisms increases (Caldas et al. 1999).

Activity of Enzymatic Biomarkers. As regards BMs, significant differences were found between climatic seasons in AChE and GST, while CAT did not record these differences (Table 2). AChE was determined in both brain and muscle, 
registering a higher mean activity $(18.32 \mathrm{U} / \mathrm{min} / \mathrm{mg}$ protein) in the brain relative to the muscle $(7.35 \mathrm{U} / \mathrm{min} / \mathrm{mg}$ protein), representing a difference slightly exceeding two orders of magnitude between the two tissues. However, both tissues show the same pattern, i.e. the activity recorded was higher in the dry season vs. the rainy season (Figure 2). In the brain, AChE showed an inhibition slightly above $16 \%$ $\left(t_{(32)}=-2.075, p<0.05\right)$ in the wet season; in the muscle, this inhibition was about $40 \%\left(t_{(20)}=-3.18, p<0.01\right)$, also in the rainy season (Table 2 ).
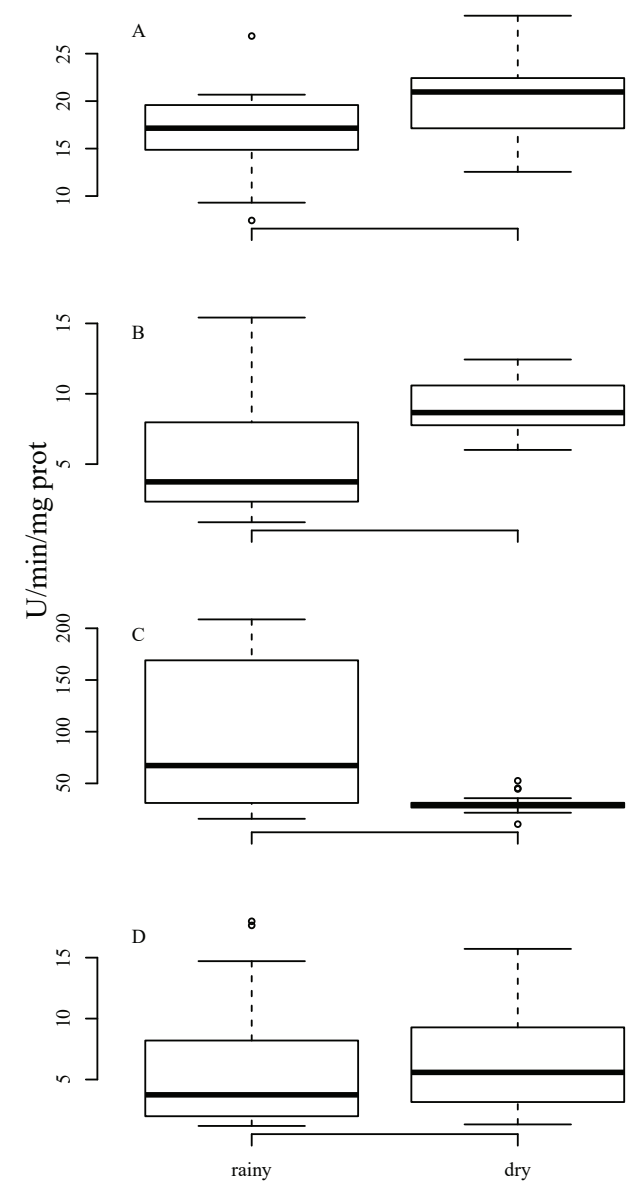

Figure 2. Activity of BMs in tissues of Mus musculus captured in agricultural fields. Data were compared between climatic seasons; AChE was evaluated in (A) brain and (B) muscle, while GST (C) and CAT (D) were analyzed in liver. Results are shown as median values, quartiles (box); activity is expressed as $\mathrm{U} /$ minute/mg protein.

AChE is considered to be the best BM for assessing exposure to organophosphate and carbamate pesticides - the main anticholinergic pesticides. However, their characteristics (poorly persistent in the environment, highly soluble in water) make it difficult to quantify them in both the environment and animal tissues (Sheffield et al. 2001). Rattner and Hoffman (1984) report the inhibition of AChE after the administration of sublethal oral doses of the organophosphate (OF) insecticide acephate to wild mice (M. musculus, $P$. leucopus and M. pennsy/vanicus); inhibition rates were similar to those reported in this study (16 to $40 \%$ ) at doses between $25 \mathrm{mg} / \mathrm{kg}$ and $100 \mathrm{mg} / \mathrm{kg}$ of food for 5 days. In addition, the inhibition rates recorded in our results are seemingly harmless for the mouse populations, as in other investigations an inhibition rate of more than $40 \%$ was found, which was not lethal in exposed mice (Dell'Omo and Shore 1996; Meyers and Wolff 1994).

Studies based on field work that characterize the inhibition of AChE in wild rodents are scarce. In this sense, our results on $\mathrm{AChE}$ inhibition (16 to $40 \%$ ) are consistent with some studies carried out in the wild in other rodent species such as Microtus pennsylvanicus (Jett 1986), M. pinetorum (Durda et al. 1989), P. maniculatus and P. leucopus (Block et al. 1999), M. musculus (Edward et al. 1983; Custer et al. 1985), and particularly in Mexico in $O$. couesi and $R$. gracilis (Chi Coyoc et al. 2016). In these works, it is concluded that the degree of inhibition found did not cause lethal acute poisoning, and population stability was not affected.

In the present work, AChE activity decreases during the wet season, when the main crops are maize, squash, and beans, involving the use of herbicides such as glyphosate or paraquat in soil preparation, in addition to insecticides for the protection of crops, including carbofuran, endosulfan or imidacloprid. The data recorded point to a higher exposure to anticholinergic chemicals in the rainy season, which, although not analyzed here, were reported by farmers as used for pest control.

Various xenobiotics cause oxidative stress from the production of reactive oxygen species (Limon-Pacheco and Gonsebatt 2009). To avoid oxidative stress, cells activate detoxification processes through antioxidants in order to reduce toxic effects, involving the two enzymes used as BMs, GST (phase II of xenobiotic metabolism) and CAT (antioxidant), i. e., these increase their activity when exposed to toxic compounds (van der Oost et al. 2003). GST activity in the mice captured exhibited significant differences between climatic seasons ( $\mathrm{W}=253, p<0.001)$, showing a higher activity in the wet vs. dry season ( 98.36 and $30.53 \mathrm{U} /$ $\mathrm{min} / \mathrm{mg}$ protein, respectively), representing a difference of nearly $77 \%$ in BM expression between both seasons (Table 2, Figure 2).

When GST is activated, it acts on toxic chemicals by increasing their water solubility, thereby facilitating their excretion from the body (van der Oost et al. 2003). The influence of pesticides on GST in mice in agricultural areas is poorly documented. A study characterized its activation in agricultural workers after exposure to carbamates and yHCH (Lukaszewicz-Hussain 2010); the latter is one of the pesticides found in tissues of some mice in this work. In this regard, GST activity increased significantly in the rainy season, suggesting that rainfall leads to the release of some xenobiotics trapped in soil, leading to an increased reaction of detoxification enzymes such as GST. A similar pattern was found in wild mice (Peromyscus spp.) in forested areas of Mexico City where GST activity was significantly higher during the rainy season (Andrade-Herrera 2011).

Contrary to all the BMs discussed above, CAT yielded no significant differences between the dry and rainy seasons (6.15 and $6.24 \mathrm{U} / \mathrm{min} / \mathrm{mg}$ protein, respectively). How- 
ever, the average values recorded in this work are higher than those reported in other (experimental) studies, where mean activity ranges from 0.2 to $2.5 \mathrm{U} / \mathrm{min} / \mathrm{mg}$ protein (Ayed-Boussema et al. 2012; Panemangalore and Baby 2000; Yilmaz et al. 2004). In this regard, catalase is a biomarker that can react in different ways, i. e., inhibition or activation, depending on various factors, mainly the dose of the xenobiotic, time of exposure, or a combination of various compounds (van der Oost et al. 2003).

In laboratory experiments, dermal exposure to various pesticides leads to increased CAT activity. For example, Panemangalore and Baby (2000) recorded a $13 \%$ increase in activity relative to its controls after 4 weeks of exposure to a mixture of OFs. Similar effects were found in other studies where rats and mice were exposed to a variety of pesticides (OF, OC, pyrethroids and neonicotinoids, among others) via ingestion, with average increases in activity of $25 \%$ (Jin et al. 2011, 2013). When pesticides are administered intraperitoneally, both effects occur. For example, Ayed-Boussema et al. (2012), recorded increased activity levels of up to three orders of magnitude in mice after the administration of multiple doses of dimethoate for 30 days; in contrast, Yilmaz et al. (2004) found a significant CAT inhibition after administering a systemic hormone herbicide for three days in albino mice (Mus musculus).

Correlation between Pesticides and BM Activity. Spearman's correlations were performed between the OC pesticides detected (per family) and the activity of BMs recorded in mice to explore the influence of these pollutants in the activity of these BM in exposed organisms. The analyses showed a single significant correlation (rho $=-0.489, p<$ 0.01 ), between drine pesticides and AChE activity in brain tissue (Table 3). In this sense, although exposure to OC pesticides causes multiple toxic effects on organisms, AChE inhibition is caused primarily by exposure to $O F$ and $C B$ pesticides (Rodríguez-Castellanos and Sánchez-Hernández 2007), which were not analyzed in the present work. However, farmers mentioned the use of mixtures of various insecticides and acaricides, including organophosphates, pyrethroids, carbamates, and neonicotinoids, particularly in watermelon crops; in addition, empty containers of these pesticides were found in agricultural fields, suggesting that these pollutants (or their mixtures) may account for the results observed.

In Mexico, few works report the effect of xenobiotic agents in wild rodents. For example, Andrade-Herrera (2011) correlated the concentrations of air pollutants in Mexico City with the activity of enzymatic biomarkers, finding a greater impact in the dry season, likely due to thermal inversions, as airborne pollutants may cause adverse effects. In contrast, this study suggests that rainfall seemingly affects to a greater extent the physiology of mice, as AChE and GST were particularly affected in the wet season. Rainfall carries and deposits toxic chemicals in soil, hence increasing their availability for rodent living in the local environment.
Table 3. Spearman's correlations between concentrations of organochlorine pesticides and characterization of the activity of the BMs analyzed in mice. Figures in bold represent significance at $p \leq 0.05$.

\begin{tabular}{lcccccccc}
\hline & \multicolumn{2}{c}{ AChE in brain } & \multicolumn{2}{c}{ AChE in muscle } & \multicolumn{2}{c}{ GST } & \multicolumn{2}{c}{ CAT } \\
& Rho & p & Rho & p & Rho & p & Rho & p \\
\hline HCHs & 0.036 & 0.842 & -0.014 & 0.937 & 0.043 & 0.805 & -0.260 & 0.131 \\
DRINES & -0.489 & 0.003 & -0.084 & 0.630 & 0.118 & 0.501 & 0.172 & 0.323 \\
ENDOSULFAN & -0.240 & 0.172 & -0.259 & 0.133 & -0.036 & 0.839 & -0.079 & 0.653 \\
DIdd & -0.093 & 0.601 & 0.022 & 0.899 & 0.008 & 0.965 & 0.061 & 0.730 \\
Chlordanes & -0.392 & 0.022 & -0.260 & 0.131 & 0.062 & 0.724 & 0.010 & 0.954 \\
Heptachlor & -0.186 & 0.293 & -0.119 & 0.497 & -0.058 & 0.741 & 0.033 & 0.849 \\
Methoxychlor & -0.192 & 0.277 & -0.068 & 0.697 & 0.099 & 0.573 & -0.072 & 0.680 \\
\hline
\end{tabular}

\section{Conclusions}

This work is the first in Mexico to show the presence of pesticides and their biochemical effects (neurotoxicity and defense response mechanisms and antioxidants) in wild mice. The study shows that mice bioaccumulate pesticides in their tissues, which poses a risk to wildlife living in agricultural fields. The use of BMs is a valuable tool for determining sublethal hazard in wildlife due to exposure to pollutants. In this work, the activity of BMs shows a higher influence of pesticides in the rainy season, likely due to the presence of various pesticides in the environment that are deposited in soil with rain. Also, the use of wild mice as bioindicators is suitable for identifying effects associated with the use of pesticides in farming areas. For future studies, it is recommended to use blood as a non-destructive matrix, besides to the fact that blood contains chemicals that were recently ingested. Other types of pesticides should also be analyzed, in addition to broadening the battery of biomarkers used, to determine other potential adverse effects and, in turn, determine in further detail which pollutants are the major disruptors of the physiology of animals exposed, as the indiscriminate use of synthetic pesticides is likely to impact the surrounding wildlife.

\section{Acknowledgements}

We thanks Xnoh Cruz community people for the facilities to work in their agricultural fields, particularly to Fausto Pacheco and family. Also, thank to CONACYT for the doctorate scholarship granted to MAH.

\section{Literature cited}

AEBl, H. 1984. Catalase in vitro. Methods in Enzymology 105:121-126.

Alcérreca Aguirre, C., R. Robles de Benito, L. Pereira Lara, and D. Amtochew Alonzo. 2009. Mamíferos de la Península de Yucatán, Guía completa. Ed. Dante. Mérida Yucatán, México.

Andrade-Herrera, M. 2011. Evaluación del efecto de la contaminación atmosférica en dos especies del género Peromyscus (Rodentia: Muridae) que cohabitan en el Parque Nacional Desierto de los Leones. Tesis de Maestría. Universidad Autónoma Metropolitana. México, D.F.

Andrade Herrera, M., G. Escalona Segura, M. González Jáuregui, R. Reyna Hurtado, J. A. Vargas Contreras, and J. Rendón von Osten. 2018. Presence of pesticides and toxicity assessment of 
agricultural soils in the Quintana Roo Mayan zone, Mexico using biomarkers in earthworms (Eisenia fetida). Artículo enviado para su publicación.

Ayed-Boussema, I., K. Ruba, A. Moussa, N. MnasRI, and H. Bacha. 2012. Genotoxicity associated with oxidative damage in the liver and kidney of mice exposed to dimethoate subchronic intoxication. Environmental Science and Pollution Research 19:458-466.

Barrett, G. W., AND R. M. Darnell. 1967. Effects of Dimethoate on Small Mammal Populations. American Midland Naturalist 77:164-175.

Bhaskar, R., AND B. Mohanty. 2014. Pesticides in mixture disrupt metabolic regulation: In silico and in vivo analysis of cumulative toxicity of mancozeb and imidacloprid on body weight of mice. General and Comparative Endocrinology 205:226-234.

Block, E. K., T. E. Lacher, L. W. Brewer, G. P. Cobb, and R. J. Kendall. 1999. Population Responses of Peromyscus Resident in lowa Cornfields Treated with the Organophosphorus Pesticide COUNTER $^{\oplus}$. Ecotoxicology 8:189-200.

BRADFORD, M. M. 1976. A Rapid and Sensitive Method for the Quantitation of Microgram Quantities of Protein Utilizing the Principle of Protein-Dye Binding. Analitical Biochemistry 72:248-254.

Buenfll-Rojas, A. M., T. Alvarez-Legorreta, And J. R. Cedeño-Vazquez. 2016. Metals and metallothioneins in Morelet's crocodile (Crocodylus moreletii) from Rio Hondo. Toxicology Letters 259:S96.

Caldas, E. D., R. Coelho, L. C. K. R. Souza, and S. C. Siba. 1999. Organochlorine Pesticides in Water, Sediment, and Fish of Paranoá Lake of Brasilia, Brazil. Bulletin of Environmental Contamination and toxicology 62:199-206.

Cárdenas, S., and A. Márquez. 2015. Persistencia de plaguicidas organoclorados en suelos, agua y sedimentos de la cuenca del Tucutunemo, Municipio Zamora, Estado Aragua. In Memorias del XXI Congreso Venezolano de la ciencia del suelo.

Ceballos, G. 2005. Orden Rodentia. Pp. 530. in Los mamíferos silvestres de México (Ceballos G., and G. Oliva, Eds.). Fondo de Cultura Económica. Ciudad de México, México.

Charruau, P., Y. Hénaut, and T. Álvarez-Legorreta. 2013. Organochlorine pesticides in nest substratum and infertile eggs of American crocodiles (Reptilia, Crocodylidae) in a Mexican Caribbean atoll. Caribbean Journal of Science 47:1-12.

Chen, X. P., T. T. Wang, X. Z. Wu, D. W. Wang, and Y. S. Chao. 2016. An in vivo study in mice: mother's gestational exposure to organophosphorus pesticide retards the division and migration process of neural progenitors in the fetal developing brain. Toxicology Research 5:1359-1370.

Chi Coyoc, T. E., G. Escalona Segura, A. Vallarino Moncada, J. A. Vargas Contreras, G. E. Castlllo Vela, and J. Lara Reyna. 2016. Organochlorine and anticholinergic pesticides in wild mice from wetland ecosystems of the Gulf of Mexico. Therya 7:465-482.

Cobos, V., M. Mora, and G. Escalona. 2006. Inhibición de colinesterasa plasmática en el zorzal pardo (Turdus grayi), expuesto a diazinón en cultivos de papaya maradol en Yucatán, México. Revista de Toxicología 23:17-21.

Custer, T. W., E. F. Hill, and H. M. Ohlendorf. 1985. Effects of wildlife of ethyl and methyl parathion applied to California
USA rice fields. California Fish and Game 71:220-224.

Dell'Omo, G., M. G. Pleskacheva, D. P. Wolfer, H. P. Lipp, and R. F. SHORE. 2003. Comparative Effects of Exposure to an Organophosphate Pesticide on Locomotor Activity of Laboratory Mice and Five Species of Wild Rodents. Bulletin of Environmental Contamination and Toxicology 70:138-145.

DelL'OMo, G., AND R. F. SHORE. 1996. Behavioral and physiological effects of acute sublethal exposure to dimethoate on wood mice, Apodemus sylvaticus. Archives of Environmental Contamination and Toxicology 31:91-97.

Durda, J. L., R. A. Powell, AND G. T. Barthalmus. 1989. Physiological and behavioral effects of guthion on pine voles,Microtus pinetorum. Bulletin of Environmental Contamination and Toxicology 43:80-86.

Edward Montz, W., P. F. SCanlon, and R. L. KIRKPatrick. 1983. Effects of field application of the anti-cholinesterase insecticide methomyl on brain acetylcholinesterase activities in wild Mus musculus. Bulletin of Environmental Contamination and Toxicology 31:158-163.

Ellman, G. L., K. D. Courtney, V. J. Andres, and R. M. Featherstone. 1961. A New and Rapid Colorimetric Determination of Acetilcholinesterase Activity. Biochemical Pharmacology 7:88-95.

Ghodrat, E. M., P. Kazem, H. Shapour, Y. Parichehr, and N. Golamreza. 2014. The effects of pyridaben pesticide on gonadotropic, gonadal hormonal alternations, oxidative and nitrosative stresses in Balb/C mice strain. Comparative Clinical Pathology 23:297-303.

GILES JR., R. H. 1970. The Ecology of a Small Forested Watershed Treated with the Insecticide Malathion: S35. Wildlife Monographs 3-81.

Givaudan, N., F. Binet, B. Le Bot, And C. Wiegand. 2014. Earthworm tolerance to residual agricultural pesticide contamination: Field and experimental assessment of detoxification capabilities. Environmental Pollution 192:9-18.

Gómez-UGalde, R. M. 2003. Efectos de la contaminación atmosférica en poblaciones de pequeños roedores silvestres (Microtus mexicanus, Peromyscus melanotis y Peromyscus difficilis) en México, D. F. Tesis de Doctorado. Universitat de Barcelona. Barcelona, España.

González Váldez, L. S., R. Irigoyen Campuzano, V. Ortega Martínez, AND S. V. Jáquez MatAS. 2013. Comportamiento de plaguicidas persistentes en el medio ambiente. Centro Interdisciplinario de Investigación para el Desarrollo Integral Regionla Unidad Durango del Instituto Politécnico Nacional 1:1-17.

Guilhermino, L., M. C. Lopes, A. P. Carvalho, and A. M. V. M. Soares. 1996. Inhibition of acetylcholinesterase activity as effect criterion in acute tests with juvenile Daphnia Magna. Chemosphere 32:727-738.

HABIG, W. H., M. J. PABST, AND W. B. JakoBY. 1974. Glutathione S-transferases: The first enzymatic step in mercapturic acid formation. The Journal of Biological Chemistry 249:71307139.

HeLSEL, D. R. 2012. Statistics for Censored Environmental Data Using Minitab and R. 2a ed. John Wiley and Sons.

Hirano, T., S. Yanal, T. Takada, N. Yoneda, T. Omotehara, N. Kubota, K. Minami, A. Yamamoto, Y. Mantani, T. Yokoyama, H. Kitagawa, and N. HosH. 2017. NOAEL-dose of a neonicotinoid pesticide, clothianidin, acutely induce anxiety-related behavior 
with human-audible vocalizations in male mice in a novel environment. Toxicology Letters 282:57-63.

Jefferies, D. J., B. Stainsby, and M. C. French. 1973. The ecology of small mammals in arable fields drilled with winter wheat and the increase in their dieldrin and mercury residues. Journal of Zoology 171:513-539.

Jett, D. A. 1986. Cholinesterase inhibition in meadow voles (Microtus Pennsylvanicus) following field applications of orthene $^{\circledast}$. Environmental Toxicology and Chemistry 5:255259.

JiN, Y., J. WANG, X. PAN, L. WANG, AND Z. Fu. 2013. cis-Bifenthrin enantioselectively induces hepatic oxidative stress in mice. Pesticide Biochemistry and Physiology 107:61-67.

Jin, Y., L. Wang, M. Ruan, J. Liu, Y. Yang, C. Zhou, B. Xu, and Z. Fu. 2011. Cypermethrin exposure during puberty induces oxidative stress and endocrine disruption in male mice. Chemosphere 84:124-130.

Johnston, J. J. 2000. Introduction to Pesticides and Wildlife. 771:1-5. in Pesticides and Wildlife (Johnston, J. J. Ed.). American Chemical Society. Washington, U. S. A.

Köhler, H. R., and R. Triebskorn. 2013. Wildlife Ecotoxicology of Pesticides: Can We Track Effects to the Population Level and Beyond? Science 341:759-765.

Latchoumycandane, C., and P. Mathur. 2002. Induction of oxidative stress in the rat testis after short-term exposure to the organochlorine pesticide methoxychlor. Archives of Toxicology 76:692-698.

Laubscher, J. A., G. R. Dutt, and C. C. Roan. 1971. Chlorinated insecticide residues in wildlife and soil as a function of distance from application. Pesticide Monitoring Journal 5:251-258.

Limón-PACHeCO, J., AND M. E. GonsebatT. 2009. The role of antioxidants and antioxidant-related enzymes in protective responses to environmentally induced oxidative stress. Mutation Research/Genetic Toxicology and Environmental Mutagenesis 674:137-147.

Lincer, J. L., AND J. A. SherbuRne. 1974. Organochlorines in Kestrel Prey: A North-South Dichotomy. The Journal of Wildlife Management 38:427-434.

Linder, G., And G. Joermann. 2001. Assessing Hazard and Risk of Chemical Exposures to wild mammals: Food-chain analysis and its role in Ecological Risk Assessment. Pp. 635-670 in Ecotoxicology of Wild Mammals (Shore, R. F., and B. A. Rattner, eds.). 1 a ed. John Wiley and Sons Ltd.

LOPAKA, L. 2013. Nondetects and Data Analysis for Environmental Data. $R$ package version.

Lukaszewicz-Hussain, A. 2010. Role of oxidative stress in organophosphate insecticide toxicity - Short review. Pesticide Biochemistry and Physiology 98:145-150.

MACKAY, D., L. S. McCARTY, AND MACLEOD, M. 2001. On the validity of classifying chemicals for persistence, bioaccumulation, toxicity, and potential for long-range transport. Environmental Toxicology and Chemistry 20:1491-1498.

MeYers, S. M., AND J. O. Wolff. 1994. Comparative toxicity of azinphos-methyl to house mice, laboratory mice, deer mice, and gray-tailed voles. Archives of Environmental Contamination and Toxicology 26:478-482.

Morales-Prieto, N., AND N. AbriL. 2017. REDOX proteomics reveals energy metabolism alterations in the liver of $M$. spretus mice exposed to p, p'-DDE. Chemosphere 186:848-863.

MoRRIS, R. D. 1968. Effects of endrin feeding on survival and reproduction in the deer mouse, Peromyscus maniculatus. Canadian Journal of Zoology 46:951-958.

Noreña-Barroso, E., R. Sima-Alvarez, G. Gold-Bouchot, and O. ZapataPerez. 2004. Persistent organic pollutants and histological lesions in Mayan catfish Ariopsis assimilis from the Bay of Chetumal, Mexico. Marine Pollution Bulletin 48:263-269.

Oksanen, J., F. G. Blanchet, M. Friendly, R. Kindt, P. Legendre, D. McGlinn, P. R. Minchin, B. R. O'Hara, G. L. Simpson, P. Solymos, M. H. H. Stevens, E. Szoecs, and H. Wagner. 2017. Vegan: Community Ecology Package. R package.

Panemangalore, M., and F. N. Bebe, 2000. Dermal exposure to pesticides modifies antioxidant enzymes in tissues of rats. Journal of environmental science and health. Part. $B$, Pesticides, food contaminants, and agricultural wastes 35:399-416.

Peakall, D. B., And McBee, K. 2001. Biomarkers for Contaminant Exposure and Effects in mammals. Pp. 551-576 In Ecotoxicology of Wild Mammals (Shore, R. F., and B. A. Rattner, eds.). John Wiley and Sons Ltd. U. S. A.

Perez-Gonzalez, E., U. G. Osuna-Martinez, M. N. Herrera-Moreno, G. D. Rodriguez-Meza, H. A. Gonzalez-Ocampo, and M. Bucio-Pacheco. 2017. Organochlorine Pesticides in Gonad, Brain, and Blood of Mice in Two Agricultural Areas of Sinaloa. Bulletin of Environmental Contamination and Toxicology 98:454-459.

Peris-Sampedro, F., I. Reverte, P. Basaure, M. Cabré, J. L. Domingo, and M. T. Colomina. 2016. Apolipoprotein E (APOE) genotype and the pesticide chlorpyrifos modulate attention, motivation and impulsivity in female mice in the 5 -choice serial reaction time task. Food and Chemical Toxicology 92:224-235.

R Core TeAm. 2016. R: A language and environment for statistical computing.

RamíreZ, J. A., and M. Lacasaña. 2001. Plaguicidas: Clasificación, Uso, Toxicología Y Medición De La Exposición. Archivos de Prevención de Riesgos Laborales. 4:67-75.

Rattner, B. A., AND D. J. Hoffman. 1984. Comparative toxicity of acephate in laboratory mice, white-footed mice, and meadow voles. Archives of Environmental Contamination and Toxicology 13:483-491.

Rendón von Osten, J., M. Memije-Canepa, and N. A. Ek-Moo. 2005. Plaguicidas Orgánicos Persistentes (POPs) en Sedimentos de la Costa Sur de Campeche, México. Pp. 249-260 in Golfo de México Contaminación e Impacto Ambiental: Diagnóstico y Tendencias (Botello, A. V., J. Rendón-von Osten, G. GoldBouchot, and C. Agraz-Hernández, Eds.). 2da. edición,). Universidad Autónoma de Campeche. Campeche, México.

Rodríguez-Castellanos, L., and J. C. Sanchez-Hernandez. 2007. Earthworm biomarkers of pesticide contamination: Current status and perspectives. Journal of Pesticides Sciences 32:360-371.

Secretaría de Agricultura, Ganadería, Desarrollo Rural, Pesca y AlimentaCión. 2014. Norma Oficial Mexicana NOM-033-SAG/ ZOO-2014, Que establece Métodos para dar muerte a los animales domésticos y silvestres. Mexico. 26 de agosto de 2015.

SAGARPA. 2015. Avance e producción agrícola con tecnificación del riego en Quintana Roo. Secretaría de agricultura, ganadería, desarrollo rural, pesca y alimentación. 
Sheffield, S. R., K. Sawicka-Kapusta, J. B. Cohen, and B. A. Rattner. 2001. Rodentia and lagomorpha. Pp. 215-314 In Ecotoxicology of Wild Mammals (Shore, F. R., and B. A. Rattner, Eds.). New York. John Wiley and Sons Ltd. U. S. A.

van der Oost, R., J. Beyer, and N. P. E. Vermeulen. 2003. Fish bioaccumulation and biomarkers in environmental risk assessment: A review. Environmental Toxicology and Pharmacology 13:57-149.

Westlake, G. E., A. D. Martin, P. I. Stanley, and C. H. Walker. 1983. Control enzyme levels in the plasma, brain and liver from wild birds and mammals in Britain. Comparative Biochemistry and Physiology Part C: Comparative Pharmacology 76:15-24. Wolfe, J. L., AND R. J. Esher. 1980. Toxicity of carbofuran and lindane to the old-field mouse (Peromyscus polionotus) and the cotton mouse (P. gossypinus). Bulletin of Environmental Contamination and Toxicology 24:894-902.

YILMAZ, H. R., E. YüKSEL, AND Y. TÜrköz. 2004. The effect of 2, 4-dichlorophenoxyacetic acid on some antioxidant enzymes in kidneys of the second cross offsprings mice. Arastirma 11:6-9.

$Z_{A R}$, J. H. 2010. Biostatistical Analysis (5th ed.). Pearson Prentice Hall. Upper Saddle River.

Zhang, H., Z. Wang, B. Lu, C. Zhu, G. Wu, and V. Walter. 2007. Occurrence of organochlorine pollutants in the eggs and dropping-amended soil of Antarctic large animals and its ecological significance. Science in China Series D: Earth Sciences 50:1086-1096.

ZHAO, Y., Y. ZHANG, G. WANG, R. HAN, AND X. XIE. 2016. Effects of chlorpyrifos on the gut microbiome and urine metabolome in mouse (Mus musculus). Chemosphere 153:287-293.

Associated editor: Lia Mendez

Submitted: February 17, 2018; Reviewed: May 17, 2018;

Accepted: July 6, 2018; Published on line: August 5, 2018. 